\title{
Alfabetização científica e tecnologica nos anos iniciais a partir do tema lixo tecnologico
}

Fabiane Fabri

Rosemari Monteiro Castilho Foggiatto Silveira

\begin{abstract}
Resumo
Para esse artigo buscou-se contemplar a problemática do lixo tecnológico para trabalhar a temática Ambiente, visando a Alfabetização Científica e Tecnológica (ACT) no ensino de Ciências. O estudo foi desenvolvido em uma turma de alunos do 20 ano do 2 - ciclo da rede Municipal de ensino da cidade de Ponta Grossa numa abordagem CTS (Ciência, Tecnologia e Sociedade), partindo do eixo temático Recursos Tecnológicos proposto pelos Parâmetros Curriculares Nacionais. A abordagem metodológica foi a qualitativa de natureza interpretativa com observação participante. Dentre as atividades organizadas pode-se citar: a visita a uma cooperativa de reciclagem, apresentações de mini-aulas pelos alunos, confecção de fôlderes, produções escritas. Ao final do estudo, percebeu-se que os alunos já conseguiam fazer reflexões sobre as questões sociais do desenvolvimento científico e tecnológico, porém enfatiza-se a necessidade de que essas reflexões continuem ocorrendo durante a sua vida escolar, pois se acredita que só dessa forma a postura reflexiva acerca da Ciência e da Tecnologia será internalizada. Salienta-se que esses são dados da dissertação de mestrado, do Programa de Pós-Graduação em Ensino de Ciência e Tecnologia da Universidade Tecnológica Federal do Paraná - Campus Ponta Grossa (UTFPR-PG)

Palavras-chave: Alfabetização Científica e Tecnológica, CTS, Ensino de Ciências, Ambiente, Anos Iniciais, Lixo Tecnológico.
\end{abstract}

\footnotetext{
Abstract

Science and technology literacy in early years theme from waste technology

For this article we attempted to address the problem of technological waste to work the theme Environment, aiming at the Scientific and Technological Literacy (ACT) in science teaching. The study was conducted in a group of students of 2 nd year 2 nd cycle of the municipal school of Ponta Grossa a scientific literacy and technological approach STS (Science, Technology and Society), based on the thematic Technology Resources proposed by the Parameters National Curriculum.
} 
The methodological approach of this study was qualitative in nature interpretation with participant observation. Among the organized activities can be mentioned: a visit to a recycling cooperative, presentations, mini-lessons for students, making folders, written productions). At the end of the study, it is noticed that although students already able to make some reflections on the social issues of scientific and technological development, it is necessary that these considerations continue to occur during their school life, it is believed that only this way the reflective stance on Science and Technology will be internalized. Please note that these are given of the dissertation, the Graduate Program in Teaching Science and Technology of Paraná Federal University of Technology Campus Ponta Grossa (PGUTFPR).

Keywords: Scientific and Technological Literacy, CTS, Science Education, Environment, Early Years, Waste Technology.

\section{Introdução}

O desenvolvimento científico e tecnológico avança em uma velocidade jamais imaginada e o impacto desse avanço afeta diretamente a sociedade. Vivendo nesse contexto as crianças, cada vez mais, se veem envoltas por tecnologias que exercem sobre elas certo fascínio, por isso a necessidade de se desenvolver uma alfabetização científica e tecnológica (ACT) em todos os níveis de ensino. Sendo os anos iniciais o começo da trajetória dos futuros cidadãos, cabe à escola, bem como à equipe pedagógica, traçarem metas para proporcionar atividades que possibilitem aos alunos um posicionamento crítico e reflexivo em relação ao meio onde se encontram.

É fator imprescindível estimular os alunos para que entendam que a Ciência está associada ao cotidiano, e que o desenvolvimento e a utilização da ciência e da tecnologia geram mudanças tanto ambientais quanto na sua forma de vida. No entanto, o que nossa experiência enquanto educadora mostra é que os conteúdos escolares continuam sendo trabalhados de forma fragmentada distante da realidade. Assim como outras disciplinas, historicamente, o ensino de Ciências tem sido realizado "como uma coleção de fatos, descrição de fenômenos, enunciados de teorias a decorar. Não se procura fazer com que os alunos discutam as causas dos fenômenos, estabeleçam relações causais, enfim, entendam os mecanismos dos processos que estão estudando". (KRASILCHICK, 1987, p. 52)

Os Parâmetros Curriculares Nacionais de Ciências Naturais (PCN, BRASIL, 1997) alertam sobre o fato da maioria da população conviver com produtos científicos e tecnológicos, mas que, devido à falta de informação, acabam não refletindo sobre questões que englobam a sua criação/produção exercendo opções subordinadas ao mercado, o que acaba impedindo o 
exercício crítico e consciente da cidadania. O bloco temático Recursos Tecnológicos contemplados pelos PCN engloba questões em relação à Ciência, Tecnologia e Sociedade apresentando algumas propostas que levam à abertura de discussões em sala de aula dentro dessa temática.

As atividades metodológicas envolvendo o ensino de Ciências precisam ser em prol de uma aprendizagem crítica, levando em consideração o que acontece com o meio onde o aluno se encontra, promovendo a construção de conhecimentos que façam sentido para os alunos. O que não pode acontecer é fazer com que os conhecimentos se tornem um "placebo pedagógico" ${ }^{1}$. A criança precisa fazer parte do mundo, associando os conhecimentos que adquire em sala com a realidade extraclasse, pois só assim a criança poderá exercer a sua criticidade que é natural, mas que ao longo dos anos, acaba sendo tolhida por um ensino tradicional que desconsidera a realidade do aluno. É preciso estimular a criticidade da criança, pois "A criança não é cidadã do futuro, mas já é cidadã hoje, e nesse sentido, conhecer ciência é ampliar a sua possibilidade presente de participação social e viabilizar sua capacidade plena de participação social no futuro". (BRASIL, PCNs,1998, p. 23)

O estilo de vida das pessoas destruindo os recursos naturais está gerando problemas ambientais que afetam diretamente suas vidas, necessitando de uma educação científica e tecnológica que conceba o posicionamento reflexivo e crítico perante esses problemas. Não é de hoje que a crise ambiental é alvo de discussões. Dessa forma, cabe aos professores envolvidos no processo educativo promover atividades em prol dessa temática possibilitando aos alunos uma reflexão crítica ampliando discussões acerca da conservação e preservação do meio do qual fazem parte.

Assim, a proposta deste artigo é apresentar o resultado de um trabalho realizado no ensino de Ciências visando a ACT, desenvolvido com uma turma de alunos do 2 - ano do 2 - ciclo da rede Municipal de ensino da cidade de Ponta Grossa numa abordagem CTS (Ciência, Tecnologia e Sociedade), partindo do eixo temático Recursos Tecnológicos proposto pelos Parâmetros Curriculares Nacionais. Para esse artigo buscou-se contemplar a problemática do lixo tecnológico para trabalhar a temática Ambiente, visando a Alfabetização Científica e Tecnológica (ACT).

Salienta-se que esses são dados da pesquisa de mestrado intitulada: O ensino de Ciências nos anos iniciais sob a ótica CTS: uma proposta de trabalho diante dos artefatos tecnológicos que norteiam o cotidiano dos alunos do Programa de Pós-Graduação em Ensino de Ciência e

${ }^{1}$ BIZZO (2008, p.12) compara o placebo pedagógico com os remédios. Um grupo de pessoas com uma determinada doença recebe um remédio para verificar sua eficácia. Outros recebem cápsulas sem qualquer medicamento. Essas cápsulas são os placebos. O autor define placebo pedagógico como uma série de conhecimentos que não tem nenhuma utilidade para o aprendiz. 
Tecnologia (PPGECT) da Universidade Tecnológica Federal do Paraná Campus Ponta Grossa (UTFPR-PR).

\section{A necessidade de uma alfabetização científica e tecnológica}

O ensino de Ciências precisa de um novo olhar. O professor precisa ter consciência que ele é a chave para que mudanças aconteçam juntamente com políticas públicas que venham ao encontro de uma reformulação. Tornarmos professores reflexivos diante das mudanças científicas e tecnológicas, buscarmos uma ACT é de suma importância, pois os alunos estão diariamente em contato com o avanço e as consequências dessa evolução científica e tecnológica. Para contemplar essa idéia o relatório da UNESCO: A Ciência para o século XXI (2003, p. 7) traz que:

"recentes descobertas de grande porte nas áreas de ciência e tecnologia são extremamente promissoras para a melhoria da humanidade. Mas, por outro lado, como bem sabemos, e como é enfatizado na Declaração de Santo Domingo, as aplicações da ciência e da tecnologia podem vir a causar danos ao meio-ambiente, geralmente provocando desastres industriais, ou desestabilizando relações sociais locais".

Contemplar as aplicações do avanço científico e suas repercussões no meio ambiente, posicionando-se perante ele e possibilitando práticas educativas que despertem a ACT, é questão imprescindível nos anos iniciais e em qualquer outro nível de ensino.

O meio ambiente é um dos eixos temáticos apresentados pelos PCNs que precisa ser abordado pelo professor em sua prática docente. A degradação desse ambiente é fato vivenciado pela sociedade, sendo assim cabe ao professor assumir uma postura e direcionar atividades contemplando a sua preservação.

Os alunos precisam conhecer para poder intervir, pois atualmente a Ciência e a Tecnologia, ao mesmo tempo em que podem ser usadas para facilitar a vida das pessoas, podem se tornar uma ameaça gerando sérios problemas ambientais e sociais. Obter o desenvolvimento sem afetar o meio ambiente é utópico, mas conhecer formas de amenizar as consequências desse desenvolvimento é algo que merece e precisa ser priorizado.

Fazer com que os alunos adquiram uma consciência ambiental para que possam intervir na natureza, compreender onde ele está inserido para poder interferir em outros locais é a finalidade do ensino de Ciências. Barros (2009, p.127) frisa algumas consequências da evolução das novas tecnologias:

"Degradação das águas, do ar e dos solos, mas também na destruição de culturas e no aumento da exclusão daqueles que não podem usufruir as vantagens concretas nem podem sonhar com as benesses anunciadas. Esse 
preço, embora de difícil estimativa, é, certamente, muito mais elevado que o custo de desenvolvimento e produção de novas tecnologias e até o momento não se viu satisfeita a aposta de que o trabalho de pesquisa virá a apontar para formas mais limpas de tecnologias".

Desenvolver atividades buscando despertar a consciência em relação ao avanço da Ciência e da Tecnologia priorizando uma alfabetização científica e tecnológica sinaliza um novo caminho a ser contemplado nos anos iniciais do ensino fundamental. Lorenzetti e Delizoicov (2001, p.3) definem:

"alfabetização científica como a capacidade do indivíduo ler, compreender e expressar opinião sobre assuntos que envolvam a Ciência, parte do pressuposto de que o indivíduo já tenha interagido com a educação formal, dominando, desta forma, o código escrito. Entretanto, complementarmente a esta definição, e num certo sentido a ela se contrapondo, partimos da premissa de que é possivel desenvolver uma alfabetização científica nas Séries Iniciais do Ensino Fundamental, mesmo antes do aluno dominar o código escrito".

Mesmo antes, de a criança dominar o código escrito nos anos iniciais é possível desenvolver atividades priorizando uma alfabetização científica, pois as crianças convivem com o avanço científico e tecnológico necessitando de uma alfabetização que contemple essas questões. Iniciar desde as primeiras séries e ir gradativamente aprofundando essa alfabetização é de fundamental importância para formar cidadãos conscientes e responsáveis.

Para isso os professores precisam de uma base educacional para o desenvolvimento de um pensamento científico. Não se trata só de uma alfabetização científica que tenha a função restrita de mobilizar o aluno, motivar, mas uma alfabetização científica que dê suporte para que as questões pertinentes à Ciência sejam realmente abordadas em sala de aula, mas também uma postura crítica diante das tecnologias. Reforçando uma educação científica no sentido de preparar o indivíduo para atuar na sociedade na qual se insere, fazendo com que o mesmo se posicione perante as situações futuras de forma crítica e reflexiva.

\section{Tecnologias x Lixo Tecnológico}

Vivemos num período marcado pelo avanço científico e tecnológico. Linsingen (2007, p.15) argumenta que a tecnologia está relacionada com automóveis, com a TV, prédios, remédios, todos os artefatos que os humanos produzem.

"Mas não são os objetos em si que são "a Tecnologia". Eles são produtos da Tecnologia, ou seja, os resultados decorrentes de uma rede de relações humanas e não humanas (reúne aspectos organizacionais, técnicos, sociais e 
culturais) que faz com que os objetos se materializem e adquiram relevância e valor".

Esse autor afirma que esses artefatos carregam, em si, interesses, idiossincrasias, limitações constituídas historicamente, valores de grupos dominantes e estão "impregnados de humanidade e se constituem como políticos". (ibidem, p.15)

Assim, a Ciência e a Tecnologia não podem ser percebidas desarticuladamente da sociedade. Enquanto a Ciência busca a compreensão do universo, a Tecnologia emprega o conhecimento científico para manipular a natureza. É evidente que a Ciência moderna depende dos avanços tecnológicos - melhores equipamentos, computadores, entre outros recursos - para que os cientistas possam observar profundamente os mistérios do universo. Mas, tanto a Tecnologia quanto a Ciência constituem-se em atividades humanas e avançam nem sempre em benefício da sociedade, alterando assim, o comportamento das pessoas.

A velocidade do avanço tecnológico é surpreendente e esse impacto acaba afetando todas as pessoas. A escola, diante desse cenário, está sendo convidada a promover a ACT a todos os alunos, nos mais variados níveis de ensino. Nos anos iniciais isso é fator decisivo, Amabis (2009, p.155 -156) contribui:

"Nos dias de hoje, o conhecimento científico afeta de tal forma nossas vidas que é imperativo que todas as pessoas educadas tenham certa compreensão da natureza e dos processos da ciência, e conheçam os principais avanços nas diferentes áreas científicas de modo a poder aplicá-los com sabedoria. Compreender como a ciência é organizada, sua natureza, seus alcances e suas limitações auxiliam os cidadãos nas tomadas de decisão em uma sociedade tecnológica e os colocam em posição de influenciar que recursos públicos a nação deve destinar à produção de conhecimento científico e a seus desdobramentos tecnológicos".

Promover reflexões acerca do avanço científico e tecnológico é de suma importância, pois esse avanço característico da modernidade está ocasionando uma crise social e ambiental. 0 estilo de vida das pessoas destruindo os recursos naturais gera problemas ambientais que afetam diretamente as suas vidas, necessitando de uma ACT que conceba o posicionamento reflexivo e crítico perante esses problemas.

Com a crescente substituição dos artefatos tecnológicos, aumenta a quantidade de lixo que se constitui em um dos problemas da sociedade atual. Existem vários tipos de lixo tecnológico como: os eletrônicos em geral, computadores, telefones celulares, cartuchos de impressoras, lâmpadas, pilhas e baterias. Para cada tipo de resíduo que cada artefato tecnológico possui é necessário uma estrutura para o seu tratamento, que a maioria das cidades não dispõe. Segundo Cardoso et al. (2007, p.4) “No Brasil, grande parte destes resíduos é destinada em aterros sem 
estrutura adequada, resultando, desta forma, na contaminação de solos e água nas proximidades destes aterros".

O ideal seria que empresas especializadas recolhessem esses materiais, mas como eles diferem na sua composição, haveria a necessidade de serem desmontados para, posteriormente, serem vendidos, o que dificulta o interesse de empresas. Não é de hoje que a crise socioambiental é alvo de discussões. Dessa forma, cabe aos professores envolvidos no processo educativo, promover atividades em prol dessa temática possibilitando aos alunos uma reflexão crítica ampliando discussões, procurando promover uma conscientização científica e tecnológica.

"Se ensina nomes científicos de agentes infecciosos e processos de desenvolvimento das doenças, mas não se reflete sobre as condições sociais que determinam a existência de muitos desses agentes em determinadas comunidades. Da mesma forma, se ilustra exemplos do cotidiano de processos de separação de materiais como catação, mas não se discute os determinantes $e$ as conseqüencias do trabalho desumano de catadores em lixões do Brasil". (Santos, 2007, p.4).

A separação de lixo reciclável como o plástico, vidro, papel e metal já se constituem em realidade vivenciada por alguns alunos, pois fazem a separação desses materiais recicláveis em suas casas e os entregam para catadores que fazem a coleta. Mas qual o destino dado aos artefatos tecnológicos quando não são mais utilizados? Como as crianças percebem a questão do Lixo Tecnológico? Assim, devido à importância do assunto e ao fato de as crianças conviverem com essa problemática foram desenvolvidas atividades para trabalhar a questão do lixo tecnológico, cujos procedimentos metodológicos são apresentados na sequência.

\section{Procedimentos Metodológicos}

A abordagem metodológica foi a qualitativa de natureza interpretativa com observação participante. $O$ estudo foi realizado em uma escola da rede municipal na cidade de Ponta Grossa numa turma composta por dezesseis alunos, do 20 ano do 20 ciclo (antiga 4 a série). Sendo nove meninos e sete meninas. A idade dos alunos foi na faixa de nove a doze anos.

As técnicas de coleta de dados foram a observação, anotações em diário de campo, gravações em áudio e vídeo transcritas na íntegra, questionários com perguntas abertas e fechadas, fotografias e atividades escritas realizadas pelos alunos.

Para o desenvolvimento do estudo, inicialmente, buscou-se obter os conhecimentos prévios dos alunos em relação às questões socioambientais que envolvem o lixo tecnológico. A partir dos dados obtidos delinearam-se as atividades a serem desenvolvidas na segunda etapa, visando proporcionar uma alfabetização científica e tecnológica. 
O estudo foi desenvolvido especialmente no conteúdo de Ciências, mas permeou de maneira interdisciplinar todos os demais conteúdos como: História quando pesquisaram a história dos artefatos tecnológicos; Geografia onde puderam identificar a localização dos bairros que possuem cooperativas de reciclagem e a localização no mapa dos países que restringem a utilização de sacolas plásticas; Português com suas produções escritas e entrevistas; Artes quando confeccionaram o folder e, Matemática, quando pesquisaram o número de sacolas disponibilizadas pelos supermercados da cidade. 0 período de realização do estudo foi de 05 de abril a 12 de maio de 2010. Sendo nove dias no mês de abril e quatro dias do mês de maio.

Salienta-se que para garantir o anonimato dos alunos, os nomes utilizados na apresentação dos dados são fictícios.

\section{Apresentação e discussão dos dados}

Na primeira fase do estudo para se obter as concepções prévias dos alunos em relação ao lixo tecnológico foram realizados alguns questionamentos que serão apresentados a seguir, juntamente, com sua análise a seguir.

Em relação às concepções prévias dos alunos quando perguntamos qual era o destino da geladeira, do celular, do liquidificador, do fogão, da batedeira, da TV que não tinham mais utilidade em suas casas.

A maioria (9) dos alunos afirmou que joga no lixo comum, como se observa na resposta de Regina: Jogo fora; outros (5) vendiam para alguém ou encaminham para o ferro velho, como enfatizou Giliard: Jogo lá no ferro velho; um afirmou que mandava arrumar ou consertava: Mandava arrumar (Jenifer). Um faz doação, como se observa na resposta de Fred: Damos para as pessoas que precisam.

A rápida evolução dos artefatos tecnológicos estimula o consumismo e aumenta a quantidade de lixo tecnológico gerando, cada vez mais, resíduos, que pela redução dos preços baixos leva o consumidor a trocá-los rapidamente. Muitas vezes, o conserto não é vantajoso. Os alunos, fazendo parte de uma geração movida pela compra, precisam ser conscientizados em relação ao consumismo. O professor, nesse cenário, precisa trazer à tona discussões sobre essa realidade. O que realmente é necessário e o que é a demanda ${ }^{1}$ ?

Partindo dessa análise, cabe ao professor realizar atividades em prol da conscientização dos alunos quanto ao descarte no lixo comum, enfatizando os problemas sociais e ambientais que essa ação pode causar futuramente. Explicar o que é o lixo tecnológico, bem como qual seria, na

\footnotetext{
${ }^{1}$ Refere-se não somente ao desejo, mas também à capacidade de aquisição de produtos e serviços pelos cidadãos ou por parte da sociedade. Difere do significado de necessidade, que se relaciona com as carências humanas, mas não obrigatoriamente com a capacidade de "compra" ou de aquisição. (NETO,199_ p.2) 
cidade onde eles moram, o lugar correto para descarte desse tipo de lixo, caso ele exista, ou entidades que se disponham ao encaminhamento desse material. Para Arnhold (2007) "o lixo proveniente de produtos tecnológicos não tem um sistema de tratamento fácil". Existem cidades que possuem empresas que tratam desse tipo de material, porém muitas, ainda, não possuem nenhuma ação nesse sentido.

Assim, com o objetivo de proporcionar reflexões sobre as suas percepções iniciais em relação à questão do lixo tecnológico e o consumismo. Os alunos receberam uma história ( $O$ celular de Marcelo) onde, após a leitura, foram incentivados a escrever o final a história.

\section{O celular de Marcelo}

Marcelo é um jovem de 14 anos e adora as tecnologias. Um tempo atrás, pediu aos seus pais um celular para se comunicar com a galera da escola. Depois de muita insistência, seus pais acabaram comprando à prestação um celular para ele, um modelo simples devido ao custo dos mais sofisticados.

Foi uma festa, Marcelo nem acreditava. Conversava com seus amigos e mandava mensagens. Com o passar do tempo, Marcelo foi percebendo que outros modelos mais modernos foram surgindo e o seu celular estava ficando ultrapassado. Sentia vergonha de usá-lo perto de seus colegas que possuíam outros mais modernos. Então, novamente ,começaram os pedidos para trocar o seu celular por outro mais moderno. Marcelo desejava um celular que tirasse fotos.

Seus pais tiveram que fazer economia para comprar o celular com que Marcelo sonhava. No seu aniversário ele acabou ganhando um mais moderno. Marcelo ficou imensamente feliz com o presente! Mas o que Marcelo vai fazer com o antigo?

\section{Quadro 1 - Texto: O celular de Marcelo}

Fonte: Autoria própria

Quatro (4) alunos apresentaram como final da história, a venda desse celular. Como afirmou Helena: Marcelo não sabia o que fazer, mas resolveu vender o celular. Então ele ganhou o seu dinheiro. Dois (2) escreveram que Marcelo reaproveitaria as peças do celular, como registrou Braian: Marcelo resolveu abrir o celular, tirar suas peças e guardar. Dois (2) afirmaram que ele jogaria no lixo, como pode ser percebido na resposta de Francis: Marcelo jogou no lixo comum sem saber que ia prejudicar o mundo. Seis (6) doariam o celular velho para alguém como registrou Rosana: Marcelo resolveu doar seu celular antigo para uma pessoa humilde e essa pessoa ficou muito feliz. Dois (2) não participaram ${ }^{1}$.

Com essa atividade foi possível abordar com os alunos a questão da discriminação, que não se restringe apenas à discriminação racial, mas também econômica em que grupos acabam

\footnotetext{
${ }^{1}$ Os exercícios relacionados a essa atividade encontram-se no guia didático, produto da dissertação de mestrado do PPGECT-PG que deu origem a este artigo, conforme já explicitado na introdução. O site de acesso é: http://www.pg.utfpr.edu.br/dirppg/ppgect/dissertacoes/defesas.php?ano=2011\&grupo=0
} 
excluindo as pessoas pelo seu baixo poder aquisitivo, ou mesmo pela forma como se vestem, falam ou vivem.

Na escola de Marcelo (personagem da história) ele se sentiu discriminado pelos demais. Foram discutidas algumas questões como o que seria prioridade. Será que a prioridade seria ter o celular? Será que a família de Marcelo não deixou de comprar outro produto que estava precisando, só para satisfazer uma vontade do filho? Em muitos lares isso acontece, basta um "bip" diferente e as pessoas já trocam o celular.

A mídia leva as pessoas a consumirem cada vez mais. O celular serve para que os pais se comuniquem com os filhos (ou vice-versa), em situações de risco ou simples comunicação social, a função seria essa. Será que ter um que tire fotos é uma prioridade? O que faz a pessoa não é o que ela tem, mas o que ela é.

Foi discutida com os alunos a diferença entre necessidade e demanda, por meio da interpretação da história, com as seguintes perguntas:

a) Em sua opinião, a família de Marcelo tinha condições para comprar um celular para o filho?

b) Em sua opinião, a mídia (propagandas) influencia as pessoas a comprarem um determinado produto?

c) Alguém aqui na sala já descartou um celular, pilha, ou algum recurso tecnológico que tinha em casa e não tinha mais utilidade?

d) Existe algum problema em descartar esse lixo tecnológico junto com o lixo comum?

e) Em sua casa é feita a separação do lixo?

f) Existe algum catador de material reciclável em sua vila?

A maioria (10) dos alunos considerou que a família de Marcelo não tinha condições para comprar um celular novo. Como afirmou Carla: Eles não tinham, mas compraram. Três (3) registraram que possuíam condições como expressou Giliard: Sim. E três (3) alunos não compareceram.

Em relação à influência da mídia na decisão das pessoas todos os alunos que participaram registraram que as propagandas acabam exercendo influência nas decisões.

Quanto ao descarte do lixo tecnológico junto com o comum, nove alunos assinalaram ser problemático o descarte e cinco escreveram que não. Dois não compareceram no dia da aula. Em relação à separação do lixo cinco (5) alunos afirmaram que não separam o lixo, e a maioria (9) disse que separa como pode ser percebido no registro de Francis: Sim, separo e dou para as pessoas que reciclam; dois alunos não compareceram. 
A maioria dos alunos (11) relatou que existe alguém que recolhe o lixo, como pode ser percebido no registro de Marcos: Sim, toda quarta-feira. Outros (3) disseram que nunca viram. Dois não compareceram.

Apesar da maioria (9) dos alunos separarem o lixo, ainda cinco não possuem essa atitude em suas casas, sendo necessário desenvolver atividades para conscientizá-los sobre essa questão.

Por meio da leitura das respostas, foram proporcionadas reflexões acerca dessas questões, como o consumismo desenfreado de produtos e esses, ora ultrapassados, ora sem utilidade, acabam se tornando um lixo tecnológico.

Em seguida foi explicado para a turma o que seria o lixo tecnológico. O objetivo dessa atividade seria perceber os impactos que o lixo tecnológico causa ao ambiente e às pessoas Os alunos, individualmente, realizaram leitura do texto (Anexo A) e em seguida, fizeram um caçapalavras, com as palavras: lixo- tecnologias- problemas-saúde- destino- ambiente- consciênciaperigos. Como pode ser visto nas figuras 1 e 2.


Figura 1 e 2 -Caça-palavras

Fonte: Fotos da pesquisa

Com o intuito de ampliar os conhecimentos dos alunos em relação ao assunto, foi realizada uma visita a uma cooperativa de recicláveis da cidade de Ponta Grossa. Segundo Delizoicov e Lorenzetti (2001, p. 11) as saídas de campo são atividades enriquecedoras e por meio delas:

"os alunos estarão realizando observações diretas, contribuindo para a alfabetização científica, na medida em que permitem, de modo sistemático, mediar o uso dos conhecimentos para melhor compreender as situações reais. Os alunos acabam utilizando todos os sentidos e não apenas a observação visual".

A visita foi organizada e agendada com antecedência, bem como foi solicitado à Secretaria do Meio Ambiente da Prefeitura Municipal de Ponta Grossa a presença de um responsável para direcionar a visita e dar as explicações necessárias.

Para a visita, a turma, juntamente com a professora, elaborou um protocolo com perguntas a serem feitas na cooperativa. 


\begin{tabular}{|c|c|}
\hline $\begin{array}{l}\text { Entrevista na cooperativa de Reciclagem } \\
\text { 1) Quando surgiram as cooperativas de } \\
\text { reciclagem na cidade? } \\
\text { 2) Quantas cooperativas de reciclagem } \\
\text { existem na cidade? } \\
\text { 3) Quantas pessoas aproximadamente } \\
\text { trabalham nessas cooperativas? } \\
\text { 4) Que ações a prefeitura está realizando } \\
\text { no sentido da reciclagem? } \\
\text { 5erde? Como funciona o programa Feira } \\
\text { 6) Quantas vilas esse programa atende? } \\
\text { 7) Como funciona a troca de recicláveis } \\
\text { por verduras? } \\
\text { 8) Quantos quilos de recicláveis dão } \\
\text { direito à troca? } \\
\text { 9) Qual a procedência dessas verduras e } \\
\text { frutas que atendem o programa Feira Verde? } \\
\text { 10) Enumere quais são essas frutas e } \\
\text { verduras }\end{array}$ & $\begin{array}{l}\text { 11) Antigamente passava nas vilas um } \\
\text { caminhão que fazia a coleta de materiais } \\
\text { recicláveis. Por que atualmente não existe mais } \\
\text { esse projeto? } \\
\text { 12) A prefeitura tem a intenção de } \\
\text { recolher esse material de forma tradicional ou a } \\
\text { criação dos PEV (Programa de Entrega Voluntária) } \\
\text { vem substituir a forma antiga? } \\
\text { 13) Qual a quantidade de lixo } \\
\text { aproximadamente essa cooperativa recolhe por } \\
\text { dia? } \\
\text { 14) Para onde vão os materiais ao chegar } \\
\text { aqui? } \\
\text { 15) A prefeitura recolhe o lixo } \\
\text { tecnológico? Por quê? } \\
\text { 16) Com relação ao lixo tecnológico existe } \\
\text { alguma ação da prefeitura quanto à destinação } \\
\text { desse material? } \\
\text { 17) Existe alguma cooperativa aqui na } \\
\text { cidade que recolhe o lixo tecnológico ou esse } \\
\text { material ainda não tem um destino correto? } \\
\text { 18) Por que materiais como lâmpadas e } \\
\text { pilhas não são recolhidos pelos PEV? } \\
\text { 19) O que se pode fazer para diminuir a } \\
\text { produção de lixo? }\end{array}$ \\
\hline & \\
\hline
\end{tabular}

No dia da visita, os alunos foram recebidos pelo responsável que os levou até uma mesa que continha todos os materiais que eles recebem ali e que são recicláveis, conforme mostra a figura 3 e 4 . Os alunos ouviram as explicações e anotavam as respostas.
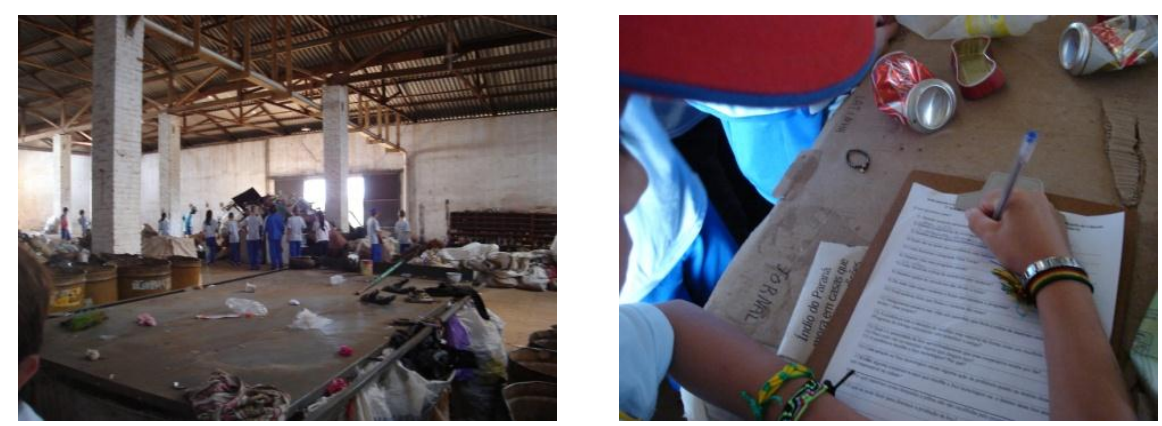

Figura 3 e 4 - Visita à cooperativa de reciclagem e entrevista Fonte: Fotos da pesquisa

Em seguida, puderam ver como é feita a separação dos materiais que ali chegam, observando as pessoas que, com muita agilidade, lançam cada tipo de material em um latão determinado. Também viram que, no local, havia uma grande quantidade de ferro velho, que estava à espera do caminhão que o retiraria dali para encaminhá-lo a local previsto, bem como um espaço destinado ao lixo tecnológico, como mostra a figura 5. 


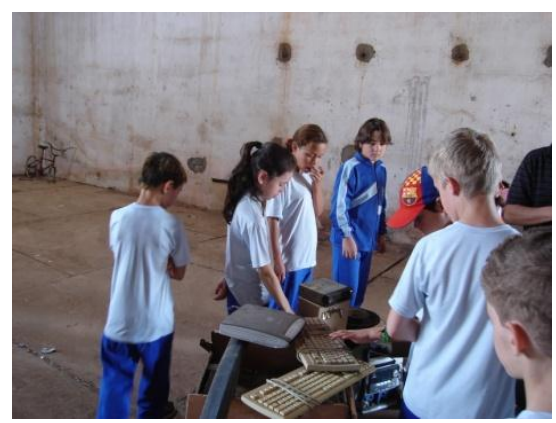

Figura 5 - Lixo Tecnológico

Fonte: Fotos da pesquisa

Segundo o responsável, o lixo tecnológico ainda em funcionamento que ali chega é levado pelos próprios catadores para serem usados em suas casas. O restante do material é vendido para uma única cooperativa da cidade que encaminha esse material para outras cidades.

Foi explicado que não existe na cidade nenhuma cooperativa que trate desse material, nem investimentos em ações da prefeitura para esse fim. Apesar de a cooperativa recolher grande parte deles, o restante acaba indo parar nos aterros. O que vai ao encontro da afirmação de Cardoso et al. (2007) que no Brasil, grande parte dos resíduos provenientes dos artefatos tecnológicos, acabam sendo despejados em aterros comuns, contaminando o solo e a água.

Ao verem a prensagem dos materiais e ficaram impressionados com a máquina. Francis relatou: Descobri a separação dos lixos e a máquina que prensa. Foi muito legal!

Os alunos também conheceram outros programas da prefeitura para incentivar a coleta de materiais recicláveis, como o Programa Feira Verde onde as pessoas trocam dois quilos de recicláveis por um quilo de verduras da época, incluindo mel.

Outro programa, também criado recentemente, é o PEV (Programa de Entrega Voluntária), ou seja, barracas colocadas em supermercados destinadas a recolher materiais que são encaminhados para as cooperativas.

As crianças acompanharam essa atividade fazendo leituras do Jornal que recebem semanalmente. Quando retornaram da visita, foram discutidas e registradas as questões da entrevista. Nessa visita, os alunos puderam conhecer uma cooperativa de reciclagem, pois nenhum deles conhecia.

Ficaram sabendo que, na cidade, existem quatro cooperativas, localizadas, respectivamente, no bairro de Uvaranas, Olarias, Nova Rússia e 31 de Março. O total de pessoas que trabalham nas cooperativas aproximadamente 100 pessoas, sendo que 25 trabalham na cooperativa visitada; o Programa Feira Verde atende 47 vilas da cidade e distribui frutas e verduras compradas em Curitiba.

Eles questionaram o porquê de não existir mais o caminhão da prefeitura com a seguinte música: Para reciclar você tem que separar vidro, plástico, papel e metal. Se você também reciclar estará ajudando a natureza salvar. Souberam que esse caminhão, atualmente, não realiza mais 
esta atividade em virtude das manutenções no programa e à troca de governos. Após a discussão em relação às questões abordadas, foi perguntado aos alunos: O que você descobriu na visita à cooperativa? As respostas evidenciam o entusiasmo dos alunos. Carla disse: Eu descobri que os homens e mulheres que pegam o lixo levam para uma cooperativa e eu achei muito legal!

Jenifer: Na visita eu aprendi como se separam os lixos.

Francis: Eu descobri o prensador de garrafas, é muito interessante. Eu gostei muito e descobri bastantes coisas.

Guto: Eu aprendi coisas e agora estou ajudando o planeta. Foi muito bom e interessante... eu gostei muito.

Também registraram a visita à cooperativa, por meio de desenhos, como se observa na figura 6 .

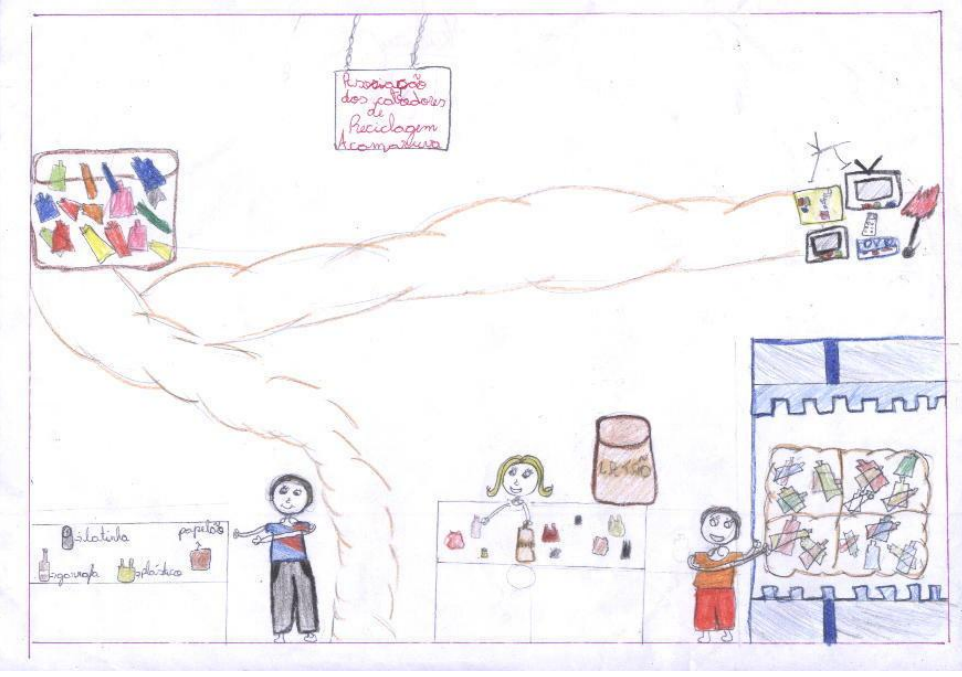

Figura 6- llustração da visita à cooperativa

Fonte: Aluna Helena

No desenho acima, a aluna registrou a realidade observada: uma mesa com os diferentes materiais que são reciclados na cooperativa, entre eles, a latinha, o papelão, a garrafa e o plástico. O instrutor responsável ao lado da mesa, fornecendo as explicações necessárias. No centro, a representação das mulheres que trabalham na separação, selecionando os materiais em respectivos latões. Em azul, a máquina de prensa que reduz o volume dos materiais, no caso, recipientes plásticos. No fundo da figura, os lixos tecnológicos que estavam armazenados lá como: TV, DVD, computadores e teclados.

Dando prosseguimento à atividade anterior, em sala de aula, foram relembradas algumas questões sobre a visita à cooperativa de reciclagem. Entre elas, a questão da cidade não possuir nenhuma cooperativa de reciclagem que recolha e dê o destino certo ao lixo tecnológico, bem como a falta de investimentos para tratar dessa problemática para o ambiente e para a 
sociedade. Em seguida os alunos assistiram a um vídeo: Lixo Tecnológico, exibido pelo programa Globo Ecologia Parte I, II e III.

Após o término do vídeo, foi discutido que lixo tecnológico não é só aquele aparelho que não funciona, pois existem produtos que saem de fábricas já com defeito, transformando-se em um lixo tecnológico. Os alunos receberam um quebra cabeça como mostra a figura 7. Recortaram as figuras e colaram no caderno como pode ser visto nas figuras 8 e 9 .

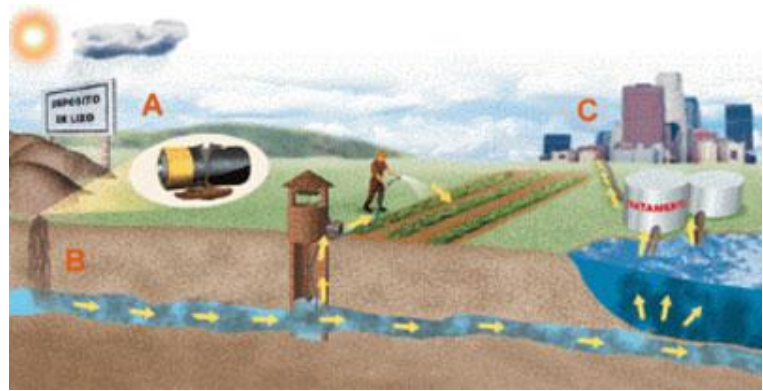

Figura 7. Quebra cabeça

Fonte: www.revistaescola.abril.com.br
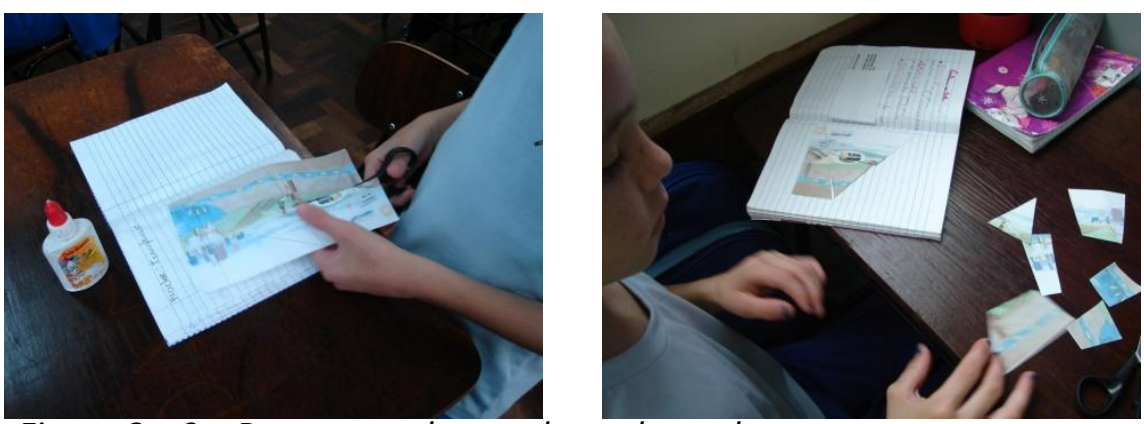

Figura 8 e 9-Recorte e colagem do quebra cabeça

"Lixo acaba voltando para casa"

Fonte: Fotos da pesquisa

Na sequência foi explicado o significado da figura. As pilhas quando ficam expostas ao sol e à chuva acabam se oxidando. Abertas, deixam escapar os metais pesados, que acabam se misturando ao líquido formado no lixo. Com novas chuvas, o líquido se infiltra no solo, atingindo o lençol freático. A água usada para irrigar plantações, contamina legumes, frutas e verduras. Os sistemas usados no tratamento da água nas cidades acabam não eliminando esses metais sendo prejudicial à saúde das pessoas. O descarte incorreto desses materiais por empresas que os produzem, em lixo comum, geram consequências desastrosas ao meio ambiente. Questionamos, durante a aula, também, o fato da cidade possuir ou não algum programa que faça a coleta de materiais como pilhas e lâmpadas.

Os alunos puderam verificar que esses materiais acabam não sendo recolhidos pelas cooperativas e vão parar nos lixões, ocasionando problemas de saúde nas pessoas. Existem alguns lugares que recolhem as lâmpadas, já as pilhas, as lojas que vendem esse material são responsáveis pela coleta, contudo na prática, isso não acontece. 
Após as explicações sobre o destino correto das pilhas, seria importante ressaltar o comentário apresentado por Lais: Minha mãe jogou uma pilha no quintal de casa que é perto da varanda e eu vi. Aí choveu. E eu falei pra ela juntar essa pilha, que ela não podia jogar. Daí ela perguntou: mas aonde que eu vou jogar essa pilha? Aí eu falei pra ela devolver na loja que ela comprou. Pertinente foi a afirmação da aluna que já está conscientizando seus familiares em relação a esse material, realizando uma ação em prol de um destino correto do material, podendo contribuir para uma nova postura. Pode-se dizer que tal postura é reflexo do trabalho que estava sendo desenvolvido com os alunos, visando uma alfabetização científica e tecnológica. Chassot (2003) contribui argumentando que o ensino de Ciências deve propiciar conhecimentos para o desenvolvimento de capacidades para que os cidadãos possam compreender o que está a sua volta, posicionando e intervindo em sua realidade. Em seguida, os alunos fizeram uma produção de texto sobre o que observaram na visita.

\begin{tabular}{|c|c|}
\hline $\begin{array}{l}\text { Nome: Francis } \\
\text { A visita à Cooperativa } \\
\text { “No dia 13/04/10, nós, do } 20 \text { ano do } 2 \text { o } \\
\text { ciclo, fomos visitar uma cooperativa de recicláveis } \\
\text { em Uvaranas. } \\
\text { Saímos às 14h e fomos de Van. } \\
\text { Chegando lá o responsável ensinou o que } \\
\text { eles reciclam, tinha uma mesa com itens. Eram vinte } \\
\text { e cinco pessoas que trabalham lá na cooperativa. } \\
\text { O Valdir mostrou oito lixos tecnológicos } \\
\text { que tinham em bom estado e tinha uma montanha } \\
\text { de ferro.E depois também mostrou a máquina de } \\
\text { prensa que prensava as coisas. } \\
\text { Voltamos de Van e eu gostei muito de lá. } \\
\text { Quero ir mais uma vez!” }\end{array}$ & $\begin{array}{l}\text { Nome: Lucas } \\
\text { A visita à Acamaruva } \\
\text { "No dia 13/04/10, nós, do } 2 \text { o ano do } 2 \text { o } \\
\text { ciclo, fomos visitar uma cooperativa de reciclagem em } \\
\text { Uvaranas. } \\
\text { Chegando lá fizemos algumas perguntas. } \\
\text { Eles reciclam quarenta e dois tipos de materiais e } \\
\text { duas mulheres separam o lixo rapidamente. } \\
\text { Cada tipo de lixo vai para um latão, juntados } \\
\text { são colocados na máquina de prensa que esmaga } \\
\text { para ocupar menos espaço. } \\
\text { E lá havia uma grande quantidade de ferro. } \\
\text { Eu gostei muito". }\end{array}$ \\
\hline
\end{tabular}

\section{Quadro 3 - Produção escrita dos alunos \\ Fonte: Aluno Francis e Lucas}

Nas produções realizadas, os alunos descreveram a visita à cooperativa. Em seus registros apresentaram a diversidade de materiais que podem ser reciclados, a máquina de prensar as embalagens foi a que mais despertou o interesse dos alunos, pois puderam observar, in loco, seu funcionamento. A prática das mulheres que separam em uma mesa os materiais, selecionando e arremessando os vários tipos de recicláveis nos latões, causou espanto pela precisão e rapidez com que fazem esse trabalho.

Em relação ao lixo tecnológico os alunos puderam ver a quantidade de eletrodomésticos que possuem utilidade e que os próprios trabalhadores levam para suas casas. Os artefatos que não têm mais serventia são vendidos para outra cooperativa da cidade que encaminha esse tipo de material, bem como os recicláveis para outras cidades. Isso reforça a afirmação de Arnhold (2007) quando coloca que o sistema de tratamento do lixo tecnológico não é algo fácil, sendo assim, poucas cidades possuem empresas especializadas na reciclagem desse tipo de material. 
A visita à cooperativa foi muito comentada pelos alunos, pois ao mesmo tempo em que observaram o funcionamento de uma cooperativa, puderam verificar, também, que o lixo gera renda e emprego para muitas famílias.

Outra atividade foi em relação às sacolas plásticas por ser um problema próximo à realidade das crianças. $O$ texto utilizado para instigar os alunos foi "Sacolas oxibiodegradáveis: solução ou problema?" (Anexo B)

O século XX se caracterizou pela "Era dos Plásticos", que sendo barato, bonito, maleável acabou se tornando a sensação do momento. Nesse mesmo cenário a filosofia do descartável se tornou algo natural, uma vez que sendo prático, maleável, leve entre outras características, acaba fazendo parte do dia a dia das pessoas.

A quantidade desse material e velocidade com que está sendo descartado geram graves problemas, fazendo com que ambientalistas e demais órgãos competentes revejam e busquem soluções para isso.

Contemplar questões do cotidiano é imprescindível nos dias atuais, com visitas à construção de um ambiente com uma melhor qualidade de vida. Assim o tema "sacolas plásticas", possibilita ao professor promover discussões com os alunos, visando levá-los a refletir sobre tais produtos, buscando leituras confiáveis em livros sobre questões relacionadas com o desenvolvimento científico e tecnológico, a fim de que se tornem mais conscientes e comecem desde cedo a exercer a sua cidadania.

Atualmente estão sendo presenciadas muitas catástrofes ambientais, que vão desde o entupimento de bueiros causando alagamentos, até o deslizamento de terras ocupadas sem planejamento. Áreas essas localizadas em locais impróprios para a habitação, como por exemplo, os lixões.

Não cabe aqui discutir a ocupação inadequada desses locais, mas refletir sobre a problemática do lixo, especificamente sobre o consumo de sacolas plásticas e sua destinação. As sacolas plásticas muito populares em nosso dia a dia, disponibilizadas por supermercados, farmácias, lojas e tantos outros estabelecimentos, tornaram-se um produto "indispensável" para quem vai às compras. No entanto, ao trazê-las, as pessoas não se preocupam com o destino que darão a elas.

Não importa a quantidade de itens que são comprados, nem o tamanho desse item. Muitas vezes as pessoas saem dos supermercados com apenas um produto embalado em uma sacola plástica, tornando-se "mecânico" o descarte desse material.

Uma lei paranaense determinou que supermercados substituíssem as sacolas fabricadas com plástico convencional pelas oxibiodegradáveis que começaram a ser produzidas em 1980 . O que se divulga é que essas demoram aproximadamente 18 meses para se decompor, mas existem muitas discussões em torno dessas sacolas. Especialistas questionam o uso, apesar dos fabricantes 
garantirem que elas desaparecem com mais rapidez na natureza. Conforme a reportagem de Vasconcelos (2008, p.1): "Estudo revela que plásticos oxibiodegradáveis não se decompõem na natureza como esperado":

\begin{abstract}
"O engenheiro de materiais Guilherme José Macedo Fechine, professor da Universidade Presbiteriana Mackenzie, de São Paulo, realizou uma bateria de testes com um tipo de plástico oxibiodegradável vendido no mercado nacional e constatou que, apesar de ele se fragmentar e virar pó, não é consumido por fungos, bactérias, protozoários e outros microorganismos - condição necessária para ser considerado biodegradável e desaparecer do solo ou da água".
\end{abstract}

Assim, essa problemática possibilitou trabalhar com os alunos a questão da informação, que é preciso ter cautela porque nem tudo que é divulgado é verdade. Bazzo e Pereira (2009) chamam a atenção dos leitores quanto à importância em ler, apresentando a facilidade que as pessoas têm, hoje, para se ter acesso às informações, por meio da variedade de canais televisivos, do acesso a internet, jornais, revistas, entre outros.

Todavia, essa facilidade se torna perigosa, pois muitas informações que circulam não são confiáveis. Nesse sentido, os autores chamam a atenção para que o leitor faça uma análise crítica do que está sendo lido. Complementando, os autores afirmam que "Ler é mesmo importante! Ler com crítica é bom. Ler criteriosamente textos previamente analisados por pessoas experientes é melhor ainda". (ibidem, p.47)

Discutir essa facilidade em obter informações, estejam elas disponíveis em páginas da internet, televisão, jornais e outras fontes é muito importante, pois os alunos de anos iniciais precisam saber que nem sempre o que circula nos meios de comunicação são informações verdadeiras. Nesse sentido, o professor precisa alertar seus alunos no que se refere à aceitação passiva dessas informações, priorizando a pesquisa para se posicionar diante de determinada informação.

Assim, inicialmente buscou-se conhecer os conhecimentos prévios dos alunos em relação ao tema "sacolas plásticas". Em relação à questão: O que é feito em sua casa com as sacolas plásticas que vêm do mercado? Todos disseram que reutilizam as sacolas que vêm do mercado para colocarem seus lixos domésticos. Contribuiu Fred: A minha mãe utiliza para colocar o lixo. Braian afirmou: Guardo em uma caixa e depois uso.

Aproveitou-se para levantar algumas questões com os alunos, em relação ao uso de sacolas plásticas. O que acontecerá com os sacos contendo lixo, deixados para a coleta, caso chova e os mesmos sejam atirados à rua? Nos lixões o que pode acontecer? Conclusão: 0 entupimento de bueiros, dificultando o escoamento da água, a circulação de pessoas e automóveis, causando enormes transtornos à vida da população. Essa realidade é presenciada e 
vivenciada por muitos alunos que adotam essa postura em armazenar seus lixos nas sacolinhas de mercado. Esses questionamentos possibilitaram a realização de reflexões sobre a problemática das sacolas plásticas no Brasil, uma vez que, circulam livremente, ao contrário de países que aboliram o seu uso devido aos prejuízos que causam ao ambiente. Fabro et al. (2007, p17) argumentam:

"Na Alemanha, as sacolas plásticas são pagas pelo consumidor nos supermercados e cultiva-se o hábito de utilizar sacos de pano reutilizáveis ou caixas de papelão no transporte de itens. Na África do Sul, foi introduzida, recentemente, uma lei que coloca na ilegalidade o uso de sacos com menos de 30 micrômetros de espessura, a fim de torná-los mais caros e fomentar a reutilização. Em Bangladesh, devido ao entupimento dos esgotos e às enchentes, tomaram-se medidas extremas: a produção, compra e uso de sacolas de polietileno é expressamente proibida implicando multas altas e prisão para os reincidentes".

Enquanto aqui, no Brasil, medidas como essas não são adotadas, precisamos conscientizar a população em relação à questão, e a escola, nesse contexto, tem que assumir o seu papel de formar cidadãos conscientes. A seguir apresentaremos os dados em relação às suas atitudes e de seus familiares diante das sacolas plásticas.

Quanto à questão: Que atitudes, tomam os alunos e seus familiares diante das sacolas plásticas? A pergunta se referia à postura adotada pelos alunos e pais quando vão às compras, em relação às sacolas plásticas, verificou-se que a maioria (15) respondeu que traz as compras em sacolas fornecidas pelos mercados e não utilizam outra forma de transporte como caixas de papelão ou carrinhos de feira. Apenas um (1) utiliza sacola retornável. Assim colaborou Guto: $A$ minha mãe comprou uma sacola de pano.

O papel do professor ao interferir nesse diagnóstico é importantíssimo. Depois de realizadas as explicações sobre as sacolas retornáveis e apresentadas à turma, percebeu-se que a maioria não conhecia esse tipo de sacolas, apenas alguns já tinham visto sacolas sendo disponibilizadas em alguns supermercados da cidade. Um aluno afirmou que sua avó possuía essas sacolas em casa, mas dificilmente as utilizava quando ia ao mercado.

Os questionamentos prosseguiram no decorrer das explicações e os alunos procuravam saber: Onde encontrar essas sacolas? Quanto custava? Você utiliza essas sacolas, professora? Quando o professor demonstra para o aluno a aproximação entre o falar e o fazer em sua prática, o ensino de Ciências se torna mais significativo. Nesse contexto Cachapuz et al. (2005, p.10) contribuem:

"Para uma renovação do ensino de ciências precisamos não só de uma renovação epistemológica dos professores, mas que essa venha acompanhada 
por uma renovação didático-metodológica de suas aulas. Agora não é só uma questão de tomada de consciência e de discussões epistemológicas, é também necessário um novo posicionamento do professor em suas classes para que os alunos sintam uma sólida coerência entre o falar e o fazer".

Essa coerência, entre o falar e o fazer é decisiva na formação dos alunos. Nos encontros posteriores, os mesmos mencionavam que tinham visto as sacolas retornáveis nos supermercados. Ao esclarecer os locais que disponibilizavam tais sacolas, bem como o fato da professora utilizar as retornáveis, não só quando está fazendo compras, mas também ao transportar os materiais escolares, o fato pode contribuir na coerência entre o falar e o fazer. Abriu-se a questão: - O que você acha que é o correto: trazer muitas sacolas plásticas juntamente com as compras? Levar sacolas retornáveis ou carrinhos de feira?

No levantamento foi possível verificar o que os alunos elegeram como correto. Quatro alunos afirmaram que o correto seria levar um carrinho de feira de casa para transportar as compras do mercado. Vejamos a resposta de Laís: Levar um carrinho de feira. Cinco registraram que o ideal seria trazer as sacolas de plástico fornecidas pelo mercado. Assim Jonas afirmou: Trazer sacolas plásticas com as compras. Sete contribuíram que levariam sacolas retornáveis de casa. Conforme Bia: Levar a sacola já de casa que é de pano.

Num primeiro momento a maioria colocou que utilizava para armazenamento de lixo, mas, após explicações, afirmaram que o correto seria levar as sacolas retornáveis para transportar as compras, mas quando questionados se eles faziam isso, os sete alunos expressaram que não tinham essa atitude. Conforme contribuiu Fred: A mãe traz do mercado e não leva de casa.

A comodidade em levar as compras em sacolas, já se tornou mecânica. Os alunos estão plantando sementes que, futuramente, se refletirão em frutos. Fazer com que os alunos insistam em suas posturas, possibilitará uma mudança, seja em casa, ou com seus vizinhos e demais pessoas envolvidas.

Em relação à quantidade de sacolas que estão circulando nos lares dos alunos, semanalmente, verificou-se que doze alunos registraram mais de dez sacolas; um afirmou cinco sacolas aproximadamente; um afirmou dez sacolas; um registrou menos de cinco sacolas e, um não respondeu. A maioria dos alunos recebe em seus lares aproximadamente mais de dez sacolas por semana.

Diante dessa questão foi sugerido que pesquisassem em um supermercado da cidade a quantidade de sacolas compradas por mês para distribuir aos seus clientes. O resultado da pesquisa apresentou que uma rede de supermercados, composta por quatro lojas na cidade, compra 500.000 sacolas/mês. Esse dado foi discutido em aulas posteriores, onde os alunos fizeram o cálculo de quantas sacolas circulam pela cidade por ano. Essas sacolas acabam sendo descartadas no lixo comum, ou são reutilizadas muitas vezes para armazenamento de lixo. 
Também foi discutida a questão de que esse dado é somente de um supermercado, a quantidade de sacolas circulando, contando com todos os mercados da cidade, fora outros

estabelecimentos que as utilizam, é algo que merece ser quantificado. Propiciar atividades como essas podem contribuir para a renovação do ensino de Ciências, assim como é fundamental o professor trabalhar com sua turma temas tão atuais e imprescindíveis na formação e atuação de seus alunos.

Temas atuais se tornam um convite aos alunos, pois investigam buscando informações, trocando ideias, possibilitando ao professor fazer as intervenções necessárias a sua aprendizagem aproveitando suas curiosidades e questionamentos, o que vai ao encontro das argumentações de Lima e Maués (2006, p.171):

"Há que se disponibilizar um conjunto de metodologias privilegiadas para ajudar a criança a construir e organizar sua relação com o mundo material, que as auxilie na reconstrução das suas impressões do mundo real, proporcionando-Ihes o desenvolvimento de novos observáveis sobre aquilo que ela investiga, indaga e tenta resolver".

O tema Sacolas Plásticas se mostrou relevante e instigou os alunos a buscar conhecimentos, pois a maioria dos artefatos tecnológicos possui em sua composição o plástico e as sacolas plásticas vieram à tona nas discussões em sala de aula. Os alunos possuem vivências em seus lares que precisam ser conhecidas pelo professor para, posteriormente, serem trabalhadas em sala de aula. Suas posturas diante dos registros analisados nos questionários e produções realizadas revelam o que eles sabem sobre o tema. Isso é importante para que o professor faça o encaminhamento de atividades metodológicas que venham para a construção do conhecimento.

A maioria da população utiliza essas sacolas de forma ingênua, pois não possuem conhecimentos que os façam refletir. As sacolas são usadas para o armazenamento de lixo e isso é um fato comum em grande parte da população.

Solicitamos aos alunos para acompanharem as notícias sobre casos de alagamentos e outras catástrofes ocasionadas pelo entupimento de bueiros pelas sacolas plásticas, que depois de usadas para carregar as compras, acabam tendo como destino, os lixões.

Foram colocadas em exposição as diferentes sacolas trazidas pelos alunos de diferentes estabelecimentos, bem como passadas de carteira em carteira para que todos os alunos realizassem uma leitura das informações nelas contidas, como o termo oxibiodegradável e sacola amiga da natureza.

Em seguida, por meio de aula expositiva e dialogada, foi explicado aos alunos o que significava o termo OXIBIODEGRADÁVEL, a origem do plástico, o petróleo, os problemas ambientais causados pelo uso inconsciente desse material, o tempo de decomposição do plástico, 
as informações passadas pela mídia em relação às sacolas, os pontos positivos e negativos em usar essas sacolas.

Também foram apresentadas aos alunos as opções para substituição das sacolas plásticas pelas retornáveis, ou carrinhos de feira e caixas de papelão. $O$ anúncio exibido por uma rede de supermercados oferecendo desconto a cada cinco itens que o cliente levar, se ignorar as sacolas plásticas. Os alunos também localizaram no mapa, conforme figuras 10 e 11 alguns países que aboliram o uso de sacolas plásticas refletindo, também, a questão em nosso país: que medidas estão sendo tomadas em relação a essa questão?


Figura 10 e 11 - Localização no mapa dos países que aboliram as sacolas plásticas Fonte: Fotos da pesquisa

Alguns registros foram anotados a respeito ao uso das sacolas. Braian contribuiu: Não pode deixar as sacolas na terra porque pode demorar 100 anos para se decompor. O correto é levar sacola retornável ou levar compras em caixas. Guto opinou: Demora muito para se decompor, é muita sacola. E tem que acabar com isto. O nosso mundo precisa da nossa ajuda. Pertinente também a afirmação de Meri: As sacolas poluem o ambiente. O correto é levar sacolas retornáveis. Jonas acrescentou: É poluente e o correto a fazer é recusar elas.

Os alunos também realizaram uma produção de texto em relação à temática sobre sacolas plásticas, o que acabou por se constituir em uma parte de um folder que foi confeccionado por eles e apresentado no decorrer da descrição das atividades desenvolvidas nesse trabalho. 


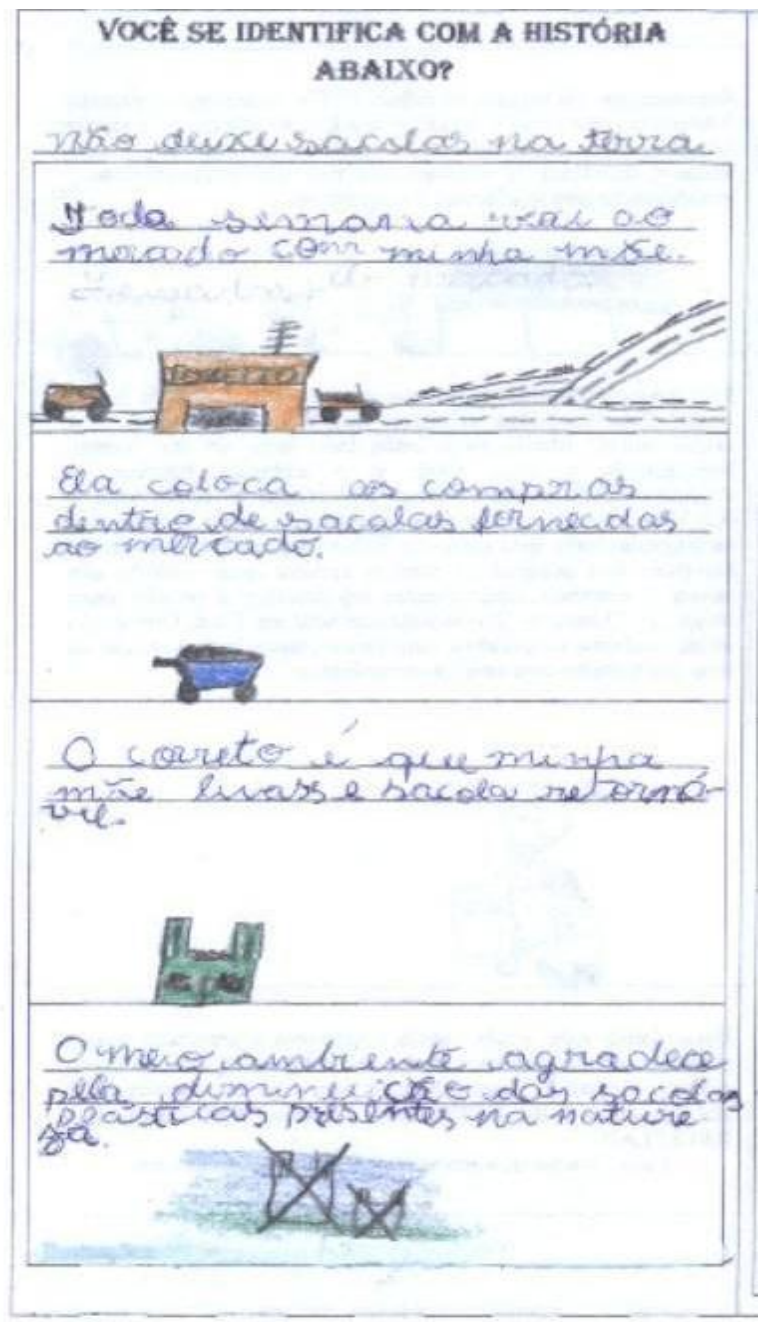

Figura 12 - Uma parte do folder produzido Fonte: Aluno Braian

Os dados foram trazidos para a sala e foram discutidas questões relacionadas à quantidade disponibilizada por mês e por ano. Assim, contribuiu Helena: São oxibiodegradável $e$ duram 18 meses para desaparecer na natureza e devemos recusar as sacolas, somente um supermercado compra 500 mil sacolas. Não apenas as sacolas são fabricadas de plástico. O plástico está presente na maioria dos artefatos tecnológicos que fazem parte do dia a dia dos alunos.

\section{Análise dos Dados}

Os resultados apresentados nesse artigo fazem parte das atividades desenvolvidas para a dissertação de mestrado que tem como tema: O Ensino de Ciências nos anos inicias sob a ótica 
CTS: uma proposta de trabalho diante dos artefatos tecnológicos que norteiam seu cotidiano. Durante a realização do trabalho que enfocou um dos eixos temáticos, Ambiente propostos pelos PCNs, observou-se as percepções iniciais dos alunos para, posteriormente, direcionar as atividades dentro dessa temática.

Esse tema se mostrou como relevante e instigou os alunos a buscar por conhecimentos. Os alunos possuem vivências em seus lares que precisam ser conhecidas pelo professor para posteriormente serem trabalhadas em sala de aula.

Suas posturas diante dos registros analisados nos questionários e produções revelam o que eles sabem sobre o tema, e permitem que o professor faça o encaminhamento de atividades metodológicas que venham ao encontro da construção de conhecimentos que serão usados por eles em seu dia a dia.

Os artefatos presentes no cotidiano de alguns alunos estavam sendo jogados diretamente no lixo comum, sem que eles tivessem consciência dos resultados perniciosos dessa ação. 0 desconhecimento das consequências nefastas da ação desordenada na separação de recicláveis, fez com que nos mobilizássemos para proporcionar atividades que promovessem uma mudança de postura.

Por meio de reflexões e discussões, visitando uma cooperativa de reciclagem da cidade, desconhecida para a maioria dos alunos, os debates se constituíram em ações práticas para perceber a importância de reciclar. $O$ trabalho com reportagens em sala de aula possibilitou aproximar a realidade fora dos muros da escola com a vivência dos alunos. Ao conhecerem uma cooperativa de reciclagem puderam perceber o seu funcionamento, as pessoas envolvidas nesse trabalho, a geração de renda entre as famílias, as ações que a cidade realiza, ou não, em prol da reciclagem.

Durante o desenvolvimento do estudo, muitas contribuições foram trazidas para a sala de aula, pois reportagens estavam sendo veiculadas pela mídia como: os vazamentos de petróleo no México, os desastres ambientais, lixo tecnológico, programas criados pela prefeitura como o PEV (Programa de Entrega Voluntária), descontos oferecidos pelos supermercados para quem recusasse sacolas plásticas. Estas reportagens foram aproveitadas para enriquecer as discussões em sala de aula.

No trabalho desenvolvido com as sacolas plásticas evidenciou a sua utilização de forma ingênua, pois não possuíam conhecimentos científicos que os fizessem refletir. As sacolas são reutilizadas para o armazenamento de lixo, e isso é um fato comum em grande parte da população. A sua utilização indiscriminada tem contribuído para problemas socioambientais como: o entupimento de bueiros, alagamentos, difícil deslocamento de pessoas e veículos, além de contribuírem para a proliferação de animais causadores de muitas doenças. 
Muitos dos alunos desconheciam as mensagens impressas nas sacolas (oxibiodegradável), além da existência de sacolas retornáveis. Por isso a importância do professor possibilitar ao aluno o acesso a esses conhecimentos que estão diretamente ligados com a realidade que vivenciam, potencializa a eles uma visão crítica e atuante junto à sociedade. Fazêlos entender o significado do termo oxi-biodegradável e a política que está por trás desse tema é fundamental.

\section{Considerações Finais}

Além de potencializar atividades diversificadas aos seus alunos é necessário que o professor dos anos iniciais possua uma formação que lhe dê suporte para propiciá-las. É necessária uma formação continuada, que busque trabalhar temas pertinentes, mostrando que a interdisciplinaridade é possível. Em muitos casos a formação obtida em seus cursos superiores acaba dando mais ênfase ao estudo da língua portuguesa e à matemática, deixando de lado o ensino de Ciências. Uma mudança de postura por parte do professor é fundamental, pois a memorização de fórmulas, datas e enunciados não contribuirá em nada nessa mudança. Fazemos parte desse ambiente e precisamos protegê-lo, despertando nos alunos do ensino fundamental a consciência socioambiental.

\section{Referências}

AMABIS,J. M. A premência da educação científica. In: WERTHEIN, J; CUNHA, C.da (org). Ensino de Ciências e Desenvolvimento: O que pensam os cientistas. São Paulo: Unesco, 2009. Disponível em: $<$ http://unesdoc.unesco.org/imagens/0018/001859/185928por.pdf. $>$ Acesso em: 9 de maio de 2010.

ARNHOLD, K. Lixo Tecnológico: que fazer com ele? Disponível em: $<$ http://www.olharvirtual.ufrj.br>. Acesso em 10 de novembro de 2007.

BARROS, H. L. de. Um novo papel da divulgação da Ciência: rumo a um contrato tecnológico. In: WERTHEIN, J; CUNHA, C.da (org). Ensino de Ciências e Desenvolvimento: O que pensam os cientistas. São Paulo: Unesco, 2009. Disponível em: <http: //unesdoc.unesco.org/imagens/0018/001859/185928por.pdf.>.Acesso em: 9 de maio de 2010.

BAZZO, W.A; PEREIRA,L.T do V. Anota aí! Universidade: estudar,aprender, viver... Florianópolis: Ed.da UFSC, 2009.

BRASIL. Ministério da Educação. Secretaria de Educação Fundamental. Parâmetros curriculares nacionais: ensino fundamental: ciências naturais. Rio de Janeiro: DP\&A, 1997. Disponível em:<http/portal.mec.gov.br/seb/arquivos/pdflivro04/pdf> Acesso em 9 de julho de 2009. 
BRASIL. Secretaria de Educação Fundamental. Parâmetros Curriculares Nacionais: terceiro e quarto ciclos do ensino fundamental; Ciências. Brasília: MEC/SEF, v. 4, 1998. Disponível em: $<$ http/portal.mec.gov.br/seb/arquivos/pdf/ciencias.pdf.> Acesso em 9 de julho de 2009.

BIZZO, N. Ciências: Fácil ou difícil. 2a ed. 10ạ impressão. São Paulo: Ed. Ática, 2008.

CARDOSO, R. da. S. et al. Ciclo de vida do produto, tecnologia e sustentabilidade: breve análise da gestão ambiental de resíduos sólidos no Brasil. XXVII Encontro Nacional de Engenharia de Produção. $2007 . \quad$ Disponível em:< www.abepro.org.br/biblioteca/ENEGEP2007 TR680488 0554.pdf>. Acesso em 15 de novembro de 2010.

CACHAPUZ, A; PEREZ,D,Gil; CARVALHO, A, M, P de;PRAIA,J; VILCHES,A. A necessária renovação do Ensino das Ciências. São Paulo: Cortez, 2005.

CHASSOT, A. Alfabetização científica: uma possibilidade para a inclusão social. Revista Brasileira de Educação, n²2, jan/fev/mar/abr. 2003. - http:<//www.scielo.br/pdf/rbedu/n22/n22a09.pdf> Acesso em 15 de novembro de 2010.

DELIZOICOV, D. LORENZETTI,L. Alfabetização científica no contexto das séries iniciais. Ensaio. v 3,no1,jun.2001. Disponível em: http:// <www.portal.fae.ufmg.br/seer/index.php/ensaio/article/viewFile/35/66> Acesso em 24 de julho de 2010.

FABRO, A. T; et al. Utilização de sacolas plásticas em supermercados. Revista Ciências do Ambiente On-Line Fevereiro, 2007. Volume 3, Número 1. Disponível em: <http://sistemas.ib.unicamp.br/be 310/ viewarticle.php?id=75>. Acesso em 23 de março de 2010 . KRASILCHICK, M. O professor e o Currículo das Ciências. São Paulo: EPU, Editora da Universidade de São Paulo, 1987.

LIMA, M. E. C.de C; MAUÉS, E. Uma releitura do papel da professora das séries iniciais no desenvolvimento e aprendizagem de Ciência das crianças. Ensaio. v. 8. № 2. dez. 2006. Disponível em:<http:www. Portal.fae.ufmg.br/seer/index.php/ensaio/article/view/115/166>. Acesso em 14 de março de 2010.

LINSINGEN, I.Von. Perspectiva educacional CTS: aspectos de um campo em consolidação na América Latina. Revista Ciência \& Ensino, vol. 1, número especial, novembro de 2007. Disponível em: $<$ http://geo25.ige.unicamp.br/ojs/index.php>. Acesso em 20 de junho de 2010.

NETO, I. R. Tecnologias sociais: conceitos \& perspectivas. [199-]. Disponível em: http// <www. Rts.org.br/bibliotecarts/estudos e pesquisas/ts_conceitos_perspectivas_ivan_rocha>. Acesso em 31 de outubro de 2010.

SANTOS, W. L. P dos. Contextualização no ensino de ciências por meio de temas CTS em uma perspectiva crítica. Ciência \& Ensino, vol. 1, número especial, novembro de 2007. Disponível 
em:<http://

geo25.ige.unicamp.br/ojs/index.php/cienciaeensino/article/viewfile/149/120>.

Acesso em 20 de maio de 2010.

UNESCO. A ciência para o século XXI: Uma nova visão e uma base de ação. 3a ed. Brasília: ABIPTI, 2003. Disponível em:<http.dominiopublico.gov.br/download/texto/ue000207.pdf>. Acesso em 23 de março de 2009.

VASCONCELOS, Y. Estudo revela que plásticos oxibiodegradáveis não se decompõem na natureza como esperado. 2008. Edição Impressa 152. Disponível em: http://www.paratyviva.com.br/ultimas/estudo-revela-que-plasticosoxibiodegradaveis-não-sedecompoem-na-natureza-como-esperado.html. Acesso em 26 de abril de 2010.

Fabiane Fabri. Professora dos anos iniciais da rede municipal de ensino da cidade de Ponta Grossa. Mestre em Ensino de Ciência e Tecnologia pela UTFPR-Campus Ponta Grossa.ffabriprof@hotmail.com

Rosemari Monteiro Castilho Foggiatto Silveira. Mestre em Tecnologia pela Universidade Tecnológica Federal do Paraná (1999), doutora em Educação Científica e Tecnológica (2007) pela UFSC. Professora da Universidade Tecnológica Federal do Paraná (UTFPR) campus de Ponta Grossa. Atualmente é professora da graduação nos cursos de Engenharia de Produção/Engenharia Mecânica, Engenharia Eletrônica e na pós-graduação atua como professora do curso de especialização em Educação Científica e Tecnológica e no mestrado profissional em Ensino de Ciência e Tecnologia da Universidade Tecnológica Federal do Paraná.castilho@utfpr.edu.br

\section{Anexos}

\section{Anexo A - Texto: Lixo Tecnológico}

O grande problema do lixo tecnológico é o destino final dado aos aparelhos que não tem mais serventia, que muitas vezes acabam no lixo comum. "Olha, eu nem sei onde 'tão' todos esses celulares, uns 'tão' na gaveta do meu quarto, outros joguei fora. Ah, e teve um que eu vendi", lembra o estudante de Sistema da Informação.

Muitas pessoas não lembram ou jogaram no lixo comum os equipamentos velhos. Essa atitude é extremamente prejudicial ao meio ambiente. Os celulares e as baterias são feitos com componentes eletrônicos altamente poluentes e que se entrarem em contato com a natureza causam um grande dano ambiental.

\section{Os perigos do lixo tecnológico}

Quando jogados no lixo comum, há grandes possibilidades de que os componentes tóxicos do lixo tecnológico penetrem no solo e entrem em contato com os lençóis freáticos. Substâncias como mercúrio, cádmio, chumbo e outros elementos tóxicos, que são encontrados nos componentes destes aparelhos, contaminam plantas e animais por meio da água, sendo possível que a ingestão dos alimentos contaminados intoxique também os humanos. "Essas 
substâncias podem provocar dores de cabeça, vômito e até serem as causadoras de câncer e problemas no sistema nervoso", garante o clínico geral, Rubens Caetano Cherobim.

Se todos jogarem fora estes lixos sem cuidado algum e no lixo doméstico, danos irreversíveis à natureza e consequentemente ao seres humanos. O prejuízo ambiental causado pelo lixo eletrônico é imenso. É preciso um controle dessa contaminação para diminuir os impactos ambientais no futuro.

Não é só o meio ambiente, nós também sofremos com o lixo tecnológico.

Quando descartado de maneira incorreta, o lixo tecnológico libera substâncias químicas, que ao entrar em contato com os seres humanos causa diversos problemas à saúde.

- Um computador tem cerca de dois quilos de chumbo e se entrar em contado com o ser humano, pode causar danos ao sistema nervoso e sangüíneo. Além disso, os PCs têm mercúrio, que pode afetar o cérebro e o cádmio que pode causar envenenamento.

- O celular traz além do chumbo, o arsênico, uma substância que pode afetar o sistema digestivo e causar doenças nos pulmões, coração e fígado.

- Já a televisão tem mercúrio e mais quantidade de chumbo: quase oito quilos.

Disponível em: http://icientifico.wordpress.com/2009/11/19/lixo-tecnologico-quem-e-o-dono/

Anexo B - Texto: Sacolas Plásticas: Solução ou problema?

Sacolas oxibiodegradáveis: Solução ou problema?

Material se decompõe em menos tempo, mas precisa de luz e calor intensos

Reportagem ANGÉLICA NEIVA E GABRIELLA PITA, especial para

Comunicação On-line. Edição GUILHERME DE SOUZA e ALINE PAVANELLI

Sacolas de plástico compõem a paisagem do centro de Curitiba

Não é segredo para ninguém que as sacolas plásticas prejudicam o meio ambiente. Não somente por seu tempo de decomposição - ela demora até 450 anos para se degradar - mas também porque quando usada para armazenar o lixo, não permite que resíduos biodegradáveis, como restos de comida, se decomponham mais rápido.

$\mathrm{Na}$ tentativa de amenizar o problema, o Paraná aprovou uma lei, em julho do ano passado, que obriga os supermercados do Estado a reduzir o impacto causado pelos utensílios. Grandes redes como Condor, Festval e Mufatto optaram pelo uso das sacolas oxi-biodegradáveis, cujo processo de degradação é mais rápido, um período aproximado de 18 meses após seu descarte.

O que poucos sabem é que isso só acontece em condições de luz e temperatura específicas e, mesmo assim, alguns especialistas questionam se o material realmente chega a ser decomposto, já que ele, ao contrário do que seu nome diz, não é biodegradável.

"O material oxi-biodegradável contém um aditivo que, na presença direta de luz e calor acima de $40^{\circ} \mathrm{C}$ entra em funcionamento, degradando o plástico. Em Curitiba quando você vê $40^{\circ} \mathrm{C}$ ?", indaga a professora de Química Orgânica da UFPR Sônia Zawadzki.

Ela explica que é a reação fotoquímica que promove a degradação e não os seres vivos, por isso é errado dizer que as sacolas são biodegradáveis. "Várias pesquisas feitas por empresas ou centros de pesquisa misturam plástico convencional com amido, que é biodegradável, mas o plástico continua não sendo biodegradável. O microorganismo come o amido, mas o plástico continua lá", aponta.

Disponível em: http://www.jornalcomunicacao.ufpr.br/node/5872.Acesso em 22/03/10 
